\title{
Effect of the Bacillus subtilis-based drug on the morphobiochemical and productive parameters of calves
}

\author{
Galina Molyanova ${ }^{1 *}$, Maxim Nogotkov $^{1}$, and Nelly Chigina ${ }^{1}$ \\ ${ }^{1}$ Samara State Agrarian University, 2, st. Uchebnaya, 446442, Kinel, Samara region, Russia
}

\begin{abstract}
The effect of Bisolbi drug based on Bacillus subtilis on the physiological, biochemical and productive parameters of calves was studied. The research and production experiment was carried out in a dairy farm "Kupinskoe" of Samara Region on 30 calves of the Holstein-Frisian breed. The drug increases the intensity of the anabolic processes in animals: the amount of total protein in blood serum of calves of the experimental group at 120 days of age was higher by $8.9 \%(p \leq 0.05)$, albumin 9.2\% ( $\mathrm{p} \leq 0.01)$, compared with control animals. The purpose of Bisolbi contributed to the increase in the intensity of carbohydrate-lipid metabolism: cholesterol was higher by $23 \%(\mathrm{p} \leq 0.01)$, glucose $0.4 \mathrm{mmol} / \mathrm{l}$ $(p \leq 0.05)$ in blood 120-day calves of the experimental group, relative to the data of the control group. It was found that the body weight of calves in the control group at 100 days of age was $105.23 \pm 2.11 \mathrm{~kg}$, in the experimental group $-108.6 \pm 2.19 \mathrm{~kg}$. The average daily gain in the experimental group was significantly higher by $0.075 \mathrm{~kg}(\mathrm{p} \leq 0.01)$. At 120 days of age, the body weight of the experimental calves was higher by $4.19 \mathrm{~kg}(\mathrm{p} \leq 0.05)$, the average daily increase by $0.080 \mathrm{~kg}(\mathrm{p} \leq 0.05)$, relative to the control animals.
\end{abstract}

\section{Introduction}

Rearing of young animals is one of the most important technological processes in animal husbandry. Full-fledged balanced feeding of calves makes it possible to realize the genetic potential inherent in their breed to obtain high-quality dairy or meat products. The use of probiotics in the diets of young farm animals during the intensification of the industry is necessary, since the optimal ratio of the microflora of the digestive tract is easily disturbed by changing the type of nutrition, rearrangement of the herd, high concentration of livestock per unit area, treatment with antibiotics and sulfonamide drugs. The scientists have proven that the use of mineral adsorbents, probiotics and other biologically active substances in addition to the main diet leads to an increase in the metabolism in the body of farm animals, an increase in the absorption of nutrients and a decrease in feed costs per unit of body weight gain [1-6].

\footnotetext{
* Corresponding author: molyanova@yandex.ru
} 
Bacillus subtilis is widespread in nature, often found in fresh and sea water, in the rhizosphere, in the soil. Bacillus subtilis is a key Gram-positive model bacterium for research in physiology and metabolism. Due to its highly efficient protein secretion system and adaptable metabolism, Bacillus subtilis microbial cells are widely used for the production of recombinant proteins, especially those associated with the production of chemicals, enzymes, and antimicrobial materials for the food industry, agriculture, and medicine [7-9].

Vafin I. T. is recommended to add mineral-probiotic concentrates (a biological supplement "Zeol-buffer") in combination with probiotics in a dose of $0.3 \mathrm{~kg}$ per animal per day to maintain and normalize metabolism and increase cow productivity, which provides economic efficiency for 1 ruble of costs from 1.55 to 2.12 rubles [10].

Alekseev I. A. during a scientific experiment on the use of probiotic feed additive basulifor has found that the average daily increase in live weight of calves on the 60th day of the experiment was higher by an average of $7.48 \%(\mathrm{P}<0.01)$, compared with control analogues [11].

In the course of scientific experiments, Gabdullin F. H. and colleagues have determined that the introduction of activated EPA "Biohummix" into the diets of a young cattle is economically feasible, since the economic efficiency per ruble of costs in heifers was 1.29 rubles, and in steers 0.44 rubles. The use of the drug at a dose of $300 \mathrm{~g}$ per animal per day provides the supply of metabolic energy in the amount of $47.3 \mathrm{MJ}$, crude protein-678.27 $\mathrm{g}$ [12].

Semenova Yu. V. has determined that the use of the sorbent biological product "Bisolbi" in swine diets in doses of 0.5 and $1.0 \%$ by weight of the feed increases average daily gain of 4.94 and of $9.19 \%$, precocity pigs when they reach a live weight of $100 \mathrm{~kg}$ for 8 and 19.9 days and reduces feed consumption per $1 \mathrm{~kg}$ of a gain of 0.8 and 1.48 EKE [13].

According to the scientific data of V. E. Ulitko and the colleagues, during the gestation period, the average daily increase in sows consuming $0.5 \%$ Bisolbi was $404.1 \mathrm{~g}$, which is $53.4 \mathrm{~g}$ or $14.88 \%$ more $(\mathrm{P}<0.001)$ than in control animals. With a further increase in the dose of "Bisolbi" in the diet of sows to $1 \%$, their average daily gains were $97.65 \mathrm{~g}$ or 27.76 $\%$ more $(\mathrm{P}<0.001)$ than in control queens [14].

Scientists Nozdrin G. A. and colleagues in the course of a scientific study have proved that the liquid forms of probiotics vetom 2.26 (active principle - Bacillus subtilis strain VKPM B-10641 and Bacillus amyloliquefaciens strain VKPM B-10643 in an amount of at least $1 \times 109 \mathrm{CFU} / \mathrm{ml}$ ) and vetom 4.24 (active principle - Bacillus amyloliquefaciens strain VKPM B-10643 in an amount of at least $1 \times 109 \mathrm{CFU} / \mathrm{ml}$ ) when used in newborn calves have a pronounced growth-stimulating effect. The growth rate of the experimental calves is directly dependent on the dose of the drugs. The highest effect was recorded in the case of the use of drugs at a dose of $1 \mathrm{l} / \mathrm{kg}$ of weight, the stimulating effect was noted within 60 days after their discontinuation [15].

In the scientific experiments of $\mathrm{Lu} \mathrm{J}$. it was shown that recombinant B. subtilis significantly reduced the alcohol-induced increase in the liver index, blood alcohol content, alanine aminotransferase, aspartate aminotransferase, and alkaline phosphatase activity in the blood serum of mice. The introduction of recombinant B. subtilis inhibited lipid peroxidation and oxidative stress in the liver of laboratory mice, as evidenced by a significant decrease in the level of malondialdehyde and the induction of total antioxidant capacity and levels of glutathione and superoxide dismutase [16].

In connection with the above, the use of modern domestic biologically active substances that improve the physiological and productive indicators of calves is an urgent topic of research. 
The aim of the research was to study the effect of the preparation Bisolbi based on Bacillus subtilis H-13 1.5×108 (LLC" Bisolbi-Inter") on the physiological and biochemical and productive indicators of calves.

\section{Material and methods}

The scientific work was conducted at the Department of "Epidemiology, pathology and pharmacology", test research laboratory, Department of biotechnology and veterinary medicine FSBEI HE "Samara state agrarian University" and the dairy farm of SUE SR "Kupinskoe" of Bezenchuksky district, Samara region. The research and production experience was conducted on calves of 60 days of age, selected according to the principle of analogues, taking into account the breed, age, sex, body weight, physiological and clinical condition and physiological maturity. The animals in the control group received the basic diet (MD), balanced on the major indicators of nutritional quality in accordance with the rules of the RAAS. Animals of the experimental group OR with the addition of a solution of Bisolbi based on Bacillus subtilis $5 \mathrm{ml}$ (60-90 day-old calves) and $10 \mathrm{ml}$ (91210 day-old calves) per head once a day for 15-20 minutes before feeding. Solutions were administered to calves through a drencher in compliance with the rules of asepsis and antiseptics.

Bisolbi is a new biological product created by LLC "Bisolbi-Inter", St. Petersburg. The composition includes Bacillus subtilis, strain H-13 and metabolites obtained during the cultivation of the strain in a concentration of at least 100 million $\mathrm{mg}$. CFU / $\mathrm{ml}$ on a mineral-silica powder filler. The drug has a positive expert opinion on the toxicological and hygienic assessment of the strain of the drug Bisolbi based on Bacillus subtilis H-13 $1.5 \times 108$ (LLC" Bisolbi-Inter") from 30.03.2010 from the Research Center for Toxicology and Hygienic regulation of Biological products (FSUN SIC TBP). The biological effect of the drug is provided by its high adsorption properties and surface activity, which allows it to adsorb a wide range of mycotoxins, pesticides, toxic metals, radionuclides contained in feed and simultaneously inhibit the development of pathogenic and conditionally pathogenic microorganisms, creating favorable conditions for the development of lacto and bifidobacteria in the digestive tract, which generally reduces the toxic load on the body and simultaneously increases the activity of a number of enzyme systems of the animal body [13].

During the research and production experience, 15 calves from each group in 60-, 70-, 80-, 90-, 100-, 110-, 120-in the daytime, the physiological and clinical status and body growth were evaluated. Blood sampling for analysis was carried out by vacuum method from the caudal vein before feeding in the morning hours from 60 to 120 days of the age every 20 days during the scientific experiment. The farm is safe for infectious diseases of cattle, vaccination and deworming of livestock is carried out according to the approved scheme. The data obtained during the experiment were processed by biometrics with the calculation of generally accepted constants and using the STADIA program.

\section{The results of the research}

Zoohygienic indicators in the calf house of SUE SR "Kupinskoe" correspond to the standards of keeping cattle. The microclimate in the room was characterized by the following indicators: the air temperature was on average $17.80 \pm 0.300 \mathrm{C}$, relative humidity$71.30 \pm 1.50 \%$, its speed $-0.17 \pm 0.06 \mathrm{~m} / \mathrm{s}, \mathrm{KEO}-1.80 \pm 0.1 \%$, the content of CO2 in the air $0.16 \pm 0.04 \%, \mathrm{NH} 3-9.00 \pm 0.20 \mathrm{mg} / \mathrm{m} 3, \mathrm{H} 2 \mathrm{~S}-2.40 \pm 0.20 \mathrm{mg} / \mathrm{m} 3$.

Such general physiological parameters as body temperature, pulse rate, respiration in calves from 60 to 120 days of age varied evenly and corresponded to their calendar day of 
development. The body temperature of the animals ranged from $38.30 \pm 1.22$ to $38.79 \pm 1.170$ $\mathrm{S}$; pulse rate from $103.49 \pm 1.31$ to $72.10 \pm 1.23$ beats per minute; respiratory rate from $38.20 \pm 0.87$ to $28.90 \pm 1.14$ respiratory movements per minute.

The effect of the drug Bisolbi based on Bacillus subtilis H-13 1.5×108 (LLC "BisolbiInter") on the biochemical parameters of calves of the Holstein-Frisian breed is shown in Table 1.

Table 1. Clinical and physiological parameters of calves' blood serum.

\begin{tabular}{|c|c|c|}
\hline \multirow{2}{*}{ Indicators, \% } & \multicolumn{2}{|c|}{ Group } \\
\hline & control & experienced \\
\hline \multicolumn{3}{|c|}{60 days } \\
\hline Red blood cells, $10^{12} / 1$ & $6.09 \pm 0.28$ & $6.16 \pm 0.29$ \\
\hline White blood cells, $10^{9} / 1$ & $7.11 \pm 0.32$ & $7.55 \pm 0.26$ \\
\hline Hemoglobin, \% & $119.20 \pm 1.32$ & $120.15 \pm 1.39$ \\
\hline Total protein, $\mathrm{g} / \mathrm{l}$ & $63.10 \pm 1.18$ & $63.30 \pm 1.26$ \\
\hline Albumins, $\mathrm{g} / \mathrm{l}$ & $21.72 \pm 0.46$ & $21.20 \pm 0.52$ \\
\hline Globulins, g/l & $41.38 \pm 1.03$ & $42.1 \pm 1.15$ \\
\hline Glucose, $\mathrm{mmol} / \mathrm{l}$ & $2.5 \pm 0.07$ & $2.7 \pm 0.10$ \\
\hline Cholesterol, $\mathrm{mmol} / \mathrm{l}$ & $2.72 \pm 0.08$ & $2.63 \pm 0.06$ \\
\hline Alkaline phosphatase IU/1 & $60.10 \pm 1.54$ & $59.50 \pm 1.78$ \\
\hline Total calcium, $\mathrm{mmol} / \mathrm{l}$ & $2.01 \pm 0.04$ & $2.13 \pm 0.05$ \\
\hline Inorganic phosphorus, $\mathrm{mmol} / \mathrm{l}$ & $1.66 \pm 0.06$ & $1.59 \pm 0.03$ \\
\hline \multicolumn{3}{|c|}{120 days } \\
\hline Red blood cells, $10^{12} / 1$ & $6.00 \pm 0.44$ & $6.32 \pm 0.37$ \\
\hline White blood cells, $10^{9} / 1$ & $6.68 \pm 0.29$ & $6.75 \pm 0.23$ \\
\hline Hemoglobin, \% & $119.20 \pm 1.95$ & $128.70 \pm 1.71 *$ \\
\hline Total protein, $\mathrm{g} / \mathrm{l}$ & $67.40 \pm 1.51$ & $73.40 \pm 1.24 *$ \\
\hline Albumins, $g / 1$ & $22.90 \pm 0.37$ & $25.01 \pm 0.29 *$ \\
\hline Globulins, g/l & $44.50 \pm 1.21$ & $48.39 \pm 1.15$ \\
\hline Glucose, $\mathrm{mmol} / \mathrm{l}$ & $2.9 \pm 0.11$ & $3.3 \pm 0.09 * *$ \\
\hline Cholesterol, mmol/1 & $2.81 \pm 0.09$ & $3.46 \pm 0.11^{* *}$ \\
\hline Alkaline phosphatase IU /1 & $63.03 \pm 1.13$ & $66.67 \pm 1.24$ \\
\hline Total calcium, mmol/1 & $2.38 \pm 0.08$ & $2.36 \pm 0.05$ \\
\hline Inorganic phosphorus, mmol/1 & $1.86 \pm 0.06$ & $1.94 \pm 0.07$ \\
\hline
\end{tabular}

The content of red blood cells, white blood cells in the peripheral blood of the experimental and control groups of animals during the use of the drug did not significantly differ. All the studied parameters were within the physiological norm.

The main function of hemoglobin is the transfer of oxygen to the tissues. In calves taking in addition to the main diet the drug Bisolbi based on Bacillus subtilis H-13 $1.5 \times 108$ (LLC "Bisolbi-Inter"), there was a significant increase in hemoglobin, compared with the control by $7.6 \%(\mathrm{p}<0.05)$, which indicates a higher intensity of metabolic processes in the body of calves.

The state of protein metabolism is determined by the total protein content. In the body, the protein performs the following functions: participates in blood clotting, maintains a constant blood $\mathrm{pH}$, performs a transport function, participates in immune responses, and many other functions. The amount of total protein in the blood serum of calves of the experimental group at 120 days of age was higher by $8.9 \%(p<0.05)$, globulins by $8.2 \%$, albumins by $9.2 \%(\mathrm{p}<0.01)$, compared with the data of control animals. The use of the drug Bisolbi based on Bacillus subtilis H-13 (LLC "Bisolbi-Inter") increases the intensity 
of anabolic processes in the body of animals, as evidenced by a higher content of total protein, specifically its albumin fraction.

One of the indicators of the state of carbohydrate-fat metabolism in the body of animals is the concentration of cholesterol. At the beginning of the scientific experiment, the cholesterol content in the blood of calves of both groups was within the physiological norm and amounted to $2.63-2.72 \mathrm{mmol} / \mathrm{l}$. The amount of cholesterol in the blood serum of experimental calves at 120 days of age exceeded the indicators of control animals by $23 \%$ $(\mathrm{p}<0.01)$. Glucose supports the normal functioning of individual cells, organs, and the body as a whole. The glucose content in the blood of calves was within the physiological norm and was at the level of 2.5-3.3 mmol/1. The results of the studies showed that the blood glucose content of 120-day-old calves of the experimental group was higher by 0.4 $\mathrm{mmol} / \mathrm{l}(\mathrm{p} \leq 0.05)$ and was $3.3 \pm 0.09 \mathrm{mmol} / \mathrm{l}$ compared to the data of the control group. The use of Bisolbi in calves for 2 months contributed to an increase in the intensity of carbohydrate-lipid metabolism.

The indicators of the state of mineral metabolism in the body are the total concentration of calcium, inorganic phosphorus and the activity of alkaline phosphatase in the blood of animals. During the scientific experiment, all the parameters were within the limits of physiological norms and no significant changes were observed: total calcium from $2.01 \pm 0.04$ to $2.38 \pm 0.08 \mathrm{mmol} / \mathrm{l}$ and inorganic phosphorus from $1.59 \pm 0.03$ to $1.94 \mathrm{mmol} / \mathrm{l}$.

The activity of alkaline phosphatase in the blood of 120-day-old calves, taking in addition to the main diet the drug Bisolbi based on Bacillus subtilis H-13 (LLC "BisolbiInter"), exceeded the indicators of control animals by $3.64 \mathrm{U} / 1$ or by $5.46 \%$, respectively. The effect of the Bisolbi-based drug on the productive performance of Holstein-Friesian breed calves is shown in Table 2 .

The body weight of calves in the control group at 100 days of age was $105.23 \pm 2.11 \mathrm{~kg}$, in the experimental group $-108.6 \pm 2.19 \mathrm{~kg}$, which is $3.37 \mathrm{~kg}$ higher. The average daily gain in the experimental group was significantly higher by $0.075 \mathrm{~kg}(\mathrm{p}<0.01)$. At 120 days of age, the body weight of the experimental calves was higher by $4.19 \mathrm{~kg}(\mathrm{p} \leq 0.05)$, the average daily increase by $0.080 \mathrm{~kg}(\mathrm{p} \leq 0.05)$, relative to the control animals. The use of the drug Bisolbi based on Bacillus subtilis H-13 (LLC "Bisolbi-Inter") to calves for 2 months contributed to an increase in the average daily growth and growth intensity of animals.

The economic calculation was carried out taking into account the costs of meat production and the revenue received from its sale at a price of 230 rubles per $\mathrm{kg}$ according to the website http://www.agro-inform.ru/index.php/czenovoj-monitoring from 15.12.2020 $\mathrm{g}$, as well as the contractual cost of the drug Bisolbi 350 rubles for 1 liter. For carrying out preventive measures for one animal during the period of the scientific experiment, $150 \mathrm{ml}$ of the drug was spent, which corresponds to the amount of 52.5 rubles. The payment for the work of a veterinary paramedic for soldering the drug to a calf daily for 2 months was 712 rubles. Based on the data obtained, the economic effect of the additional profit received at the end of the research and production experience was calculated. The use of the Bisolbi drug contributed to an increase in the live weight of the animal and the possible profit from the sale of calf meat in the experimental group was higher by 137 rubles from each head. 
Table 2. Dynamics of growth and weight indicators of calves.

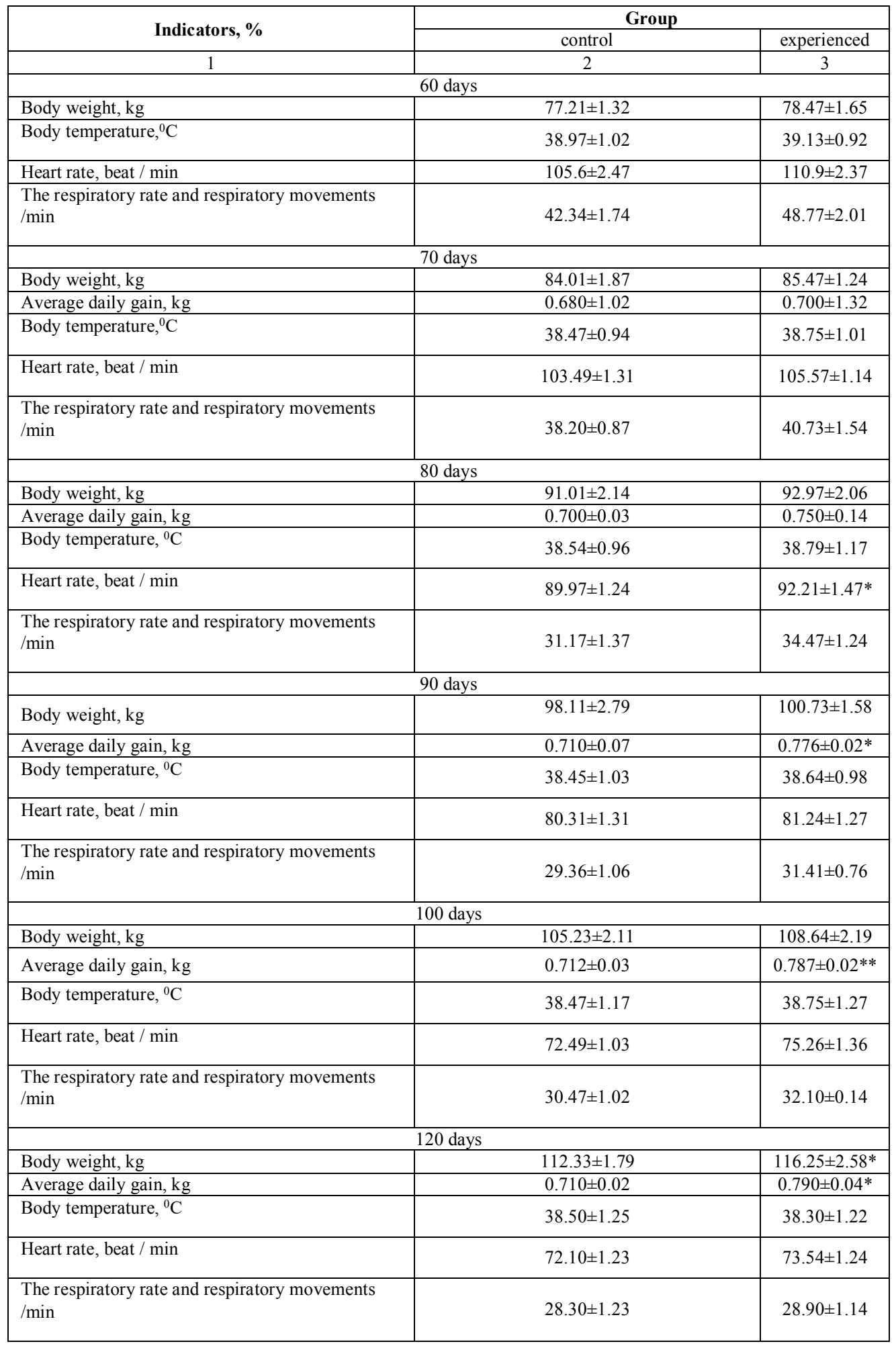




\section{Conclusion}

The prescription of the drug Bisolbi based on Bacillus subtilis H-13 (LLC "Bisolbi-Inter") to calves of the Holstein-Frisian breed in a dose of 5-10 ml per head daily from the age of 60 days allowed to increase the intensity of metabolic processes in the body of animals and, accordingly, to improve productive indicators. Based on the conducted research, we can recommend Bisolbi as a dietary supplement for young cattle in order to increase the productive performance of animals and contributes to the conditional additional profit of 137 rubles per head.

\section{References}

1. S.V. Diatkine, V.V. Akhmetova, Scientific notes of the Kazan State Academy of Veterinary Medicine. Bauman, 214, 148-154 (2013)

2. N.V. Fisenko, Agrarian science, 10, 14-15 (2020)

3. N.M. Chernogradskaya, R. L. Sharvadze, M. F. Grigoriev, A. I. Grigorieva, Agrarian science, 5, 40-44 (2020)

4. V. S. Grigoriev, G. V. Molyanova, V. I. Maximov, Acta Naturae (Russian version), 1, 194 (2016)

5. G.V. Molyanova, V.V. Ermakov, V.S. Grigorev, Correction of physiological, biochemical and productive indicators of farm animals using mineral sorbent, In the collection: BIO Web of Conferences. International Scientific-Practical Conference “Agriculture and Food Security: Technology, Innovation, Markets, Human Resources" (FIES 2019), 00011 (2020)

6. S. Yasue, J. Sawai, M. Kikuchi M. et al., Biolocontrol science, 19(3), 113-119 (2014)

7. A.N. Irkitova, A.V. Grebenshchikova, E.S. Yatsenko, et al., Ukrainian journal of ecology, 8(2), 365-370 (2018)

8. K. Zhang, Su LQ, J. Wu, Annual Review of Food Science and Technology, 11, 295318 (2020)

9. Y. Su, C. Liu, H. Fang, et al., Micribial cell factories, 19(1), article 173 (2020)

10. I.T. Vafin, Scientific notes of the Kazan State Academy of Veterinary Medicine named after N. E. Bauman, 241(1), 44-47 (2020)

11. I.A. Alekseyev, I. V. Tsarevsky, R. A. Yegorov, Veterinary doctor, 1, 59-64 (2019)

12. F. H. Gabdullin, T. M. Zakirov, A. Kh. Volkov, Sh. K. Shakirov, Scientific notes of the Kazan State Academy of Veterinary Medicine named after N. E. Bauman, 219, 94-100 (2014)

13. Yu. V. Semenova, L. A. Pykhtina, A. V. Shuklina, Bulletin of the Ulyanovsk State Agricultural Academy: a scientific and theoretical journal. Ulyanovsk: UlGAU, 4(40), 164-168 (2017)

14. B. E. Ulitko, L.A. Pykhtina, Yu.V. Semyonova, et al., Reserve and use of nutrients by sows when enriching their diets with the pre-probiotic supplement Bisolbi, Agrarian science and education at the present stage of development: experience, problems and ways to solve them: materials of the VIII International Scientific and Practical Conference-Ulyanovsk, 99-104 (2017)

15. G. A. Nozdrin, A. G. Nozdrin, A. B. Ivanova, et al., Achievements of science and technology of the agroindustrial complex, 10, 60-62 (2012)

16. J. Lu, , Y.B. Lyu, M.T. Li, et al., Journal of functional food, 49, 342-350 (2018) 